\title{
ІНФОРМАЦІЙНІ ТЕХНОЛОГІЇ ОЦІНЮВАННЯ ВПЛИВУ СТРЕСУ НА РЕЗУЛЬТАТИ ТЕСТОВОГО КОНТРОЛЮ ЗНАНЬ ЛІКАРІВ. АНАЛІТИЧНИЙ ОГЛЯД. ПЕРШЕ ПОВІДОМЛЕННЯ
}

\author{
О. П. Мінцер, С. П. Кошова \\ Національна медична академія післядипломної освіти імені П. Л. Шупика
}

\begin{abstract}
Проаналізовано методики кількісного та інтегрального оцінювання впливу стресу в лікарів у процесі тестування їхніх знань під час атестації. Обґрунтовано проблеми, що виникають при дослідженні стресів у навчальній діяльності. Проведений аналіз теоретичних та емпіричних досліджень стресових станів лікарів при навчанні під час безперервного професійного розвитку дозволяє стверджувати, що ознаки стресового стану в лікарів під час складання іспитів досить добре вивчені, але ідентифікація їх та рівень відповідності стресу не мають математичного підтвердження. Тому висловлена думка, що управління стресом можливе лише шляхом використання індивідуальних прогностичних характеристик на основі статистичного моделювання. Представлено загальні критерії оцінювання стресового стану за об'єктивними показниками. Показано, що досягнення об'єктивних оцінок компетентності, знань та вмінь лікарів під час комп'ютерного тестування повністю залежить від забезпечення ефективної адаптації до зовнішніх і внутрішніх обставин іспиту. Також постулюється, що неодмінною складовою процесу комп'ютерного іспиту є його комплементарна до особистості організація процесу, в результаті чого емоційне сприйняття процесу навчання буде позитивним, іспити фрормуватимуть позитивну самооцінку, процес засвоєння знань стане систематичним і цілісним.
\end{abstract}

Ключові слова: стрес, стресогенні чинники, інтегральні оцінки, інфрормаційні технології, безперервний професійний розвиток лікарів, копінг-процес, тестовий контроль знань, прогнозування стресу, просрілактика стресу.

\section{INFORMATION TECHNOLOGIES FOR ASSESSING THE STRESS IMPACT ON THE RESULTS OF TEST CONTROL OF DOCTORS KNOWLEDGE. ANALYTICAL REVIEW. THE FIRST MESSAGE}

\section{Shupyk National Medical Academy of Postgraduate Education}

\begin{abstract}
The methods of quantitative and integral assessment of the stress of doctors in the process of testing their knowledge during the attestation are analyzed. The problems, which arise during research of stresses in educational activity, are grounded. The analysis of theoretical and empirical studies of the stressful states in doctors during the course of continuous professional development made it possible to postulate that the signs of a stressful state in doctors during the examinations were well studied, but their identification and the level of conformity of stress has no mathematical proof. Therefore, it is considered that stress management is possible only through the use of individual prognostic characteristics on the basis of statistical simulation. The general criteria for assessing the stress state according to objective indicators are presented. It is shown that the achievement of objective assessments of competence, knowledge and skills of doctors during computer testing depends entirely on ensuring effective adaptation to the external and internal circumstances of the exam. It is also postulated that an integral part of the process of computer exam is its complementary to the personality organization of the process, resulting in the emotional perception of the learning process will be positive, examinations will form a positive self-esteem, the process of learning will become systematic and coherent.
\end{abstract}

Key words: stress, stress factors, integral assessments, information technologies, continuous professional development of doctors, coping process, test control of knowledge, stress prediction, stress prevention.

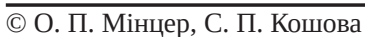




\title{
ИНФОРМАЦИОННЫЕ ТЕХНОЛОГИИ ОЦЕНИВАНИЯ ВЛИЯНИЯ СТРЕССА НА РЕЗУЛЬТАТЫ ТЕСТОВОГО КОНТРОЛЯ ЗНАНИЙ ВРАЧЕЙ. АНАЛИТИЧЕСКИЙ ОБЗОР. ПЕРВОЕ СООБЩЕНИЕ
}

\author{
О. П. Минцер, С. П. Кошевая \\ Национальная медицинская академия последипломного образования имени П. Л. Шупика
}

\begin{abstract}
Анализируются методики количественной и интегральной оценки влияния стресса у врачей в процессе тестирования их знаний во время аттестации. Обосновано проблемы, возникающие при исследовании стрессов в учебной деятельности. Проведенный анализ теоретических и эмпирических исследований стрессовых состояний у врачей при обучении во время непрерывного профессионального развития позволил утверждать, что признаки стрессового состояния у врачей во время сдачи экзаменов достаточно хорошо изучены, но идентисрикация их и уровень соответствия стресса не имеют математического подтверждения. Поэтому высказано мнение, что управление стрессом возможно лишь путем использования индивидуальных прогностических характеристик на основе статистического моделирования. Представлены общие критерии оценки стрессового состояния по объективным показателям. Показано, что достижение объективных оценок компетентности, знаний и умений врачей во время компьютерного тестирования полностью зависит от обеспечения эффрективной адаптации к внешним и внутренним обстоятельствам экзамена. Также постулируется, что непременной составляющей процесса компьютерного экзамена является его комплементарная к личности организация процесса, в результате чего эмоциональное восприятие процесса обучения будет положительным, экзамены будут фрормировать положительную самооценку, процесс усвоения знаний станет систематическим и целостным.
\end{abstract}

Ключевые слова: стресс, стрессогенные фракторы, интегральные оценки, информационные технологии, непрерывное профессиональное развитие врачей, копинг-процесс, тестовый контроль знаний, прогнозирование стресса, просрилактика стресса.

Вступ. Жодній проблемі в літературі не приділялося стільки уваги, скільки стресу. Однак, психологічний стрес залишається, як і десятиліття тому, однією з актуальних «хвороб століття» та $€$ серйозну загрозу працездатності й якості життя населення розвинутих країн світу. На думку багатьох авторів, вирішення комплексу пов'язаних із цим питань потребує інтенсивних міждисциплінарних досліджень. Разом із тим, по відношенню до більшості напрямів вивчення стресу на сьогодні не досягнуто не лише концептуальної, але і термінологічної єдності. Немає й інтегральних кількісних характеристик стресу.

Також мають особливості проблеми, пов'язані зі впливом стресу на процедури оцінювання знань у лікарів під час безперервного професійного розвитку (БПР). По-перше, акумулюються вікові, гендерні та когнітивні асиметрії. Слід також додати те, що освітня система постійно видозмінюється, відбувається широке впровадження комп’ютерних технологій, до котрих старше покоління лікарів не звикло. Це веде за собою виникнення складних стресових ситуацій, зокрема при складанні іспитів.

Мета роботи: узагальнення тенденцій створення кількісних методик оцінювання впливу стресу під час процедур комп’ютерного тестування лікарів, а також технологій зниження його негативних наслідків.
Результати та їх обговорення. Сучасна психологічна наука розмежовує поняття «фізіологічний» i «психологічний» стрес. Фізіологічний стрес виникає як результат впливу зовнішніх факторів, тоді як психологічний має в основі сприйняття ситуації, в котрій перебуває людина, як складної, загрозливої, що викликає появу таких емоцій, як тривога, страх, гнів [13].

Особливий інтерес для завдань нашого дослідження має різновид психологічного стресу - iнформаційний стрес. Він пов' язаний із стресогенними впливами складових особливостей діяльності особистості в різних сферах, насамперед інформаційного навантаження. Саме воно $є$ визначальним у навчальному процесі. Суттєву увагу дослідники відводять екзаменаційному стресу (під екзаменаційним стресом зазвичай розуміють емоційну, розумову та фізіологічну напруженість людини, яка складає іспит(и)), як однієї з основних причин появи напруженості. Факторами, що призводять до його появи, вважають порушення режиму сну, підвищення інтелектуального навантаження, емоційні переживання, зменшення інтенсивності рухової активності, а також особистісні фактори, такі як, наприклад, рівень тривожності [14].

Наголошується також, що очікування іспиту та психологічне напруження, яке пов'язано 3 цим, проявляються в людей у вигляді різноманітних 
форм (страх перед іспитом, переживання через очікування отримання негативної оцінки за іспит тощо) [16]. Значні розумові, емоційні, інформаційні, фізичні навантаження зумовлюють стан високого нервово-психічного напруження через необхідність адаптації до складання іспитів Ці поведінкові прояви супроводжуються активними вегетативними реакціями та безпосередньо на підсумковому контролі вони можуть проявитися через неможливість відтворити теоретичний матеріал, порушенні мовлення, читання тощо [16].

Зазначені думки практично не викликають суперечень. Водночас, існують різні погляди на виникнення та перебіг стресових реакцій. Одні дослідники констатують стан стресу за фізіологічними показниками, не зважаючи на суб'єктивні переживання особистості, інші розглядають стрес тільки на фазі адаптації організму, або в контексті психотравмуючих стресових розладів, обходячи динамічний аспект стресової реакції.

Загальні відомості про стрес, що потрібні для інформаційного моделювання процесу. Складність діагностики стресового стану полягає в тому, що у структурі психічного стану розрізняють три підсистеми.

Ієрархічна підсистема включає в себе фізіологічний, психофізіологічний, психологічний і соціально-психологічний рівні організації стресового стану. Друга підсистема розкриває наявність суб'єктивних (переживання) і об' єктивних (те, що спостерігається) сторін. Нарешті, остання поєднує в собі три групи характеристик: загальні, особливі і індивідуальні. Тільки зважаючи на всі ці рівні організації психічних станів, ми можемо робити висновок про наявність того чи іншого стресового стану .

До зазначеної складності діагностики стресового стану додається досить складна структура критеріїв фіксації реакції особистості на стресовий подразник. Як відомо, в процесі формування стресового стану можна прослідкувати участь трьох систем людини (моторна - забезпечує рухову реакцію людини (так в стресовому стані посилюється тонус м'язів); вегетативна — підвищення частоти серцевих скорочень, артеріального тиску при стресі; психічна сфера - зміна динаміки пізнавальних процесів і перевага позитивних або негативних емоційних переживань) [10, 11].

Провідною психологічною характеристикою стресу є напруженість, що супроводжується зміною інтенсивності багатьох процесів в організмі і психіці із їх значним підвищенням або зниженням.

Для розуміння впливу стресу на організм особистості слід наголосити на основних характеристиках його прояву. До основних форм прояву стресу можна віднести поведінкові, емоційні, інтелектуальні та фізіологічні.

Поведінкові прояви можна розділити на 4 групи: порушення психомоторики (зміна ритму дихання, надлишкова напруга м'язів); зміна стилю життя (зміни в режимі дня, порушення сну); професійні порушення (зниження ефективності діяльності, підвищена втомлюваність); порушення соціально-рольових функцій (зростання конфліктності та агресивності).

Емоційні прояви стресу першочергово проявляються в загальному емоційному фоні, який набуває негативного, песимістичного забарвлення. За умови тривалої дії стресу зростає рівень тривожності, зневіра у власні сили та зниження самооцінки, що при затяжному впливі стресу може призвести до розвитку депресії. За умови такого емоційного фону частішають прояви неадекватних емоційних реакцій (гнів, агресія, дратівливість) [9]. Варто зазначити, що негативні емоційні стани одночасно $\epsilon$ і передумовами виникнення та розвитку стресів. Дослідження навчальних стресів демонструє, що страх перед майбутніми проблемами провокує появу тривожності, невпевненості, відчуття безпорадності тощо.

Когнітивні прояви стресу охоплюють порушення: уваги (складнощі щодо концентрації уваги, звуження поля уваги, підвищена здатність відволікатися від реалізації завдань), мислення (порушення логіки мислення, труднощі у прийнятті рішень, зниження творчої активності), пам'яті (труднощі у відтворенні інформації, погіршення показників оперативної пам'яті).

Фізіологічні прояви стресу охоплюють майже всі системи органів організму людини і проявляються у травній, серцево-судинній та дихальній системах. До основних показників відносять підвищення частоти серцевих скорочень, зростання артеріального тиску, порушення роботи шлунково-кишкового тракту. Порушення нормального ритму діяльності окремих органів і їх систем призводять до комплексних фізіологічних порушень (зниження імунітету, підвищений рівень втоми, зміна маси тіла у бік збільшення або зменшення) [6]. 
Психологічний стрес проявляється в емоційних переживаннях, мотиваційно-вольових, поведінкових і когнітивних сферах. Інтегральна оцінка рівня стресу передбачає системну діагностику індивідуального стрес-реагування. Таке завдання $є$ непростим, адже необхідно оцінити багаторівневі прояви стресу. Систематизація і розробка адекватних психодіагностичних засобів для виявлення багатогранних проявів стресу набуває виключно наукового та прикладного значення [13].

Суб’єктивні параметри психологічного стресу $€$ тонкими індикаторами психічної стійкості і можуть опосередковано характеризувати відношення до стресогенних факторів. У випадку стресу як трансактного процесу він є процесом взаємодії суб’єкта з оточенням. Сучасні учені, розглядаючи стрес як трансактний процес, виділяють в структурі стресового епізоду декілька елементів: усвідомлення стресора та його оцінювання; порушення гомеостазу, пов’язані зі стресом емоції і когнітивні процеси; копінгова реакція; результат копінгу та нове оцінювання ситуації [5].

Варто зауважити, що стрес не завжди має негативне забарвлення, оскільки може мобілізувати можливості особистості для вирішення поставлених перед нею задач. Це можливе через використання адаптаційних ресурсів людини. Будемо розуміти під останніми ряд соціально-психологічних та індивідуальних характеристик, що визначають ступінь адаптованості особистості в конкретних соціальних умовах та забезпечують ефективне пристосовування до умов середовища [1]. До адаптаційних ресурсів організму, зазвичай, відносять анатомо-фізіологічні властивості особистості; нервово-психічну стійкість, самооцінку, особливості побудови контакту з оточуючими, моральну нормативність, рівень групової ідентифікації; автономність; рефлексію, емпатію, саморегуляцію; емоційність особистості як сукупність адаптаційних емоційних реакцій на шкідливі для організму фізіологічні та психологічні зрушення [11] тощо.

Підкреслимо, що небезпека стресових станів полягає в тому, що вони утворюють механізм замкненого кола: з одного боку, стресові реакції мають активізувати адаптаційні ресурси особистості для подолання складної життєвої ситуації, з іншого, самі зміни як у фізіологічній, так і в психологічній організації людини, зумовлені стресом, потребують пошуку механізмів та засобів перебудови звичного режиму функціонування, тобто адаптації до стресового стану [3]. Отже, людині необхідно майже водночас адаптуватися як до проблемної ситуації, що викликав стрес, так і до змін, спровокованих стресовим станом організму та психіки.

Основні ознаки стресового стану в лікарів під час складання іспитів - зміна поведінки (підвищена дратівливість і неадекватні реакції), зниження активності, постійна зневіра, втрата контролю над ситуацією, небажані реакції організму (прискорене серцебиття, тахікардія тощо). Вони досить добре вивчені [19, 21], але ідентифікація їх та рівень відповідності стресу не мають математичного підтвердження.

Тому важливим є використання прогностичних характеристик на основі статистичного моделювання.

Аналітичні узагальнення щодо корекції впливу стресу на процедури комп'ютерних іспитів у лікарів та провізорів. Насамперед, зауважимо, що різні види несприятливих функціональних станів (стомлення, монотонія, тощо) можуть суттєво вплинути на результати комп’ютерного тестування як й неадекватні реакції при стресах. Тому зрозуміло, що прогнозування стресових реакцій має велике наукове і прикладне практичне значення, оскільки дозволяє заздалегідь виявляти осіб, у яких можливе порушення функціонального стану під час тестових іспитів, і проводити з ними відповідну роботу в плані психопрофілактики стресу.

Натепер існують різні методи прогнозування реакцій людини на стрес. Їхнє основне завдання полягає в обліку індивідуальних психічних і фізіологічних особливостей особистості і екстраполяції отриманих даних на аналогічні ситуації у майбутньому. Умовно всі підходи розподіляють на дві групи: використання лінійних технологій та методи багатовимірного математичного аналізу.

До першої групи належать:

1) використання ідентичних стресорів (наприклад, вивчення психологічних і вегетативних реакцій тих, хто навчається, на одному іспиті дає можливість прогнозувати характер і рівень пережитого ними стресу на іншому);

2) використання дозованих тестових стресів (вплив сильних зорових, звукових і тактильних подразників);

3) уявне моделювання стресових ситуацій (методи нейролінгвістичного програмування);

4) прогнози на основі психологічних тестів і опитувальників;

5) математичні моделі (простої, множинної регресії, таксономій тощо); 
6) використання кореляційних плеяд;

7) застосування індивідуальних онтологій;

8) створення за допомогою різних пристроїв модельної стресової ситуації, яка за своїми параметрами була б досить близька до ситуації реальної.

До багатовимірних рішень відносяться:

1) моделювання надійності;

2) системні моделювання ситуації [16].

Всі вони мають досить велику кількість недоліків, серед яких найголовніші - недостатній облік мотивації індивіда, відсутність даних щодо індивідуальної кореляції показників, неможливість у кожному конкретному випадку отримати повний набір показників тощо.

Але головне - використання моніторингових технологій навіть в умовах неповного і неточного переліку показників дозволяє отримати важливі практичні результати [15].

Подолання стресу здійснюється, зазвичай, за допомогою поведінкової адаптації. І. Б. Дерманова в цьому контексті пропонує розглядати такі форми поведінки, як пристосування до середовища, перетворення середовища і власне удосконалення [8]. За Д. А. Андреєвою адаптація - це процес вироблення оптимального стилю цілеспрямованого функціонування особистості в конкретних умовах для виконання нових навчальних і практичних завдань. При цьому людина може набувати особистісних якостей, а не просто пристосовуватися до умов нового середовища [1].

Особливе місце в аналізі формування, розвитку та засобів подолання стресу посідають питання адаптаційних ресурсів людини, головне завдання яких - пристосувати людину до надмірних навантажень або загрозливих ситуацій.

Потреба в розробці нових програм психологічної адаптації лікарів у стресових для них ситуаціях, для розробки та вдосконалення яких варто враховувати як зовнішні, так і внутрішні, глибинні детермінанти ефективного пристосування до умов складання іспитів, певною мірою очевидна.

Серед стратегій поведінки особистості у стресовому стані можна виокремити ті, що зумовлюють підвищення активності, спрямованої на продовження діяльності; ті, які сприяють досягненню стабільності психічного стану завдяки зменшенню активності; ті, що дозволяють досягнути бажаної ефективності без додаткових зусиль шляхом перепланування та кращої організації праці [2, 22].
Повна зосередженість на проблемі, що постала перед людиною, відсторонення від інших видів діяльності дійсно сприяють вирішенню проблемної ситуації, проте у деяких випадках підвищена хаотична активність, зумовлена надмірною фіксацією на актуальній проблемі, унеможливлює планування майбутнього i, як наслідок, не дозволяє індивіду всебічно осмислити ситуацію, внести корективи у існуючий план дій та підвищити самоефективність.

Зниження активності може проявлятися в обережності, нерішучості, перечікуванні: відмові від прийняття рішення, активних дій «тут і зараз» для вирішення нагальних проблем або взагалі заперечення наявності проблемної ситуації. Водночас, намагаючись впоратися зі стресом, людина здебільшого спирається не лише на власні ресурси, а й шукає різноманітної підтримки у найближчого оточення - популярними є безпосередня допомога, поради, співпереживання та співчутливе ставлення. Обговорення своїх почуттів, реакції на них, конструювання власної версії подій, варіативної для кожного зі слухачів, сприяють відстороненню людини від емоційного переживання чи хоча б зменшенню його інтенсивності [24]. Зниження емоційного напруження можливе також і шляхом переносу негативних емоцій на інших людей та на самого себе (аутоагресія).

Необхідність розробки адекватних методичних засобів для оцінки індивідуальної стійкості до стресу диктується трьома важливими обставинами: загальною стійкістю до психологічного стресу, що традиційно розглядається як професійно важлива риса в напружених видах діяльності; індивідуальною стійкістю, що опосередковує зв'язок між рівнем об'єктивно відчутного стресу і розвитком різноманітних соматичних захворювань $[7,8]$; некомпенсованою дією інтенсивних стрес-факторів [1].

Важливість оцінки індивідуальної стійкості до стресу відображена в наявності багатьох діагностичних методик, які спрямовані на вимірювання ступеню його прояву. Окрім традиційних методів, спрямованих на оцінку індивідуально-психологічних характеристик як предикторів психологічної надійності, емоційної стійкості і схильності до розвитку стресу, останніми роками розробляються власне психологічні тести для вимірювання цих індивідуальних особливостей [3].

Сучасні дослідження вказують на те, що стійкість до стресу не $є$ статичною властивістю індивіда. 
Багатогранність феномену стійкості до стресу, а також провідну роль мотиваційних і когнітивних факторів у його структурі відмічали багато науковців [4], що обумовило розширення досліджень у напряму когнітивно-трансактних теорій стресу [5].

Більшість сучасних як вітчизняних, так і зарубіжних учених під копінгом розуміють сукупність когнітивних і поведінкових зусиль, спрямованих на оволодіння специфічними зовнішніми і внутрішніми вимогами (і конфліктами між ними), що оцінюються як напружуючі або як такі, що перевищують ресурси особистості [11].

Після взаємодії стресора опосередкованим особистісним фактором є процес оцінювання, тобто судження про стресову подію з різних поглядів $[17,18]$. Оцінювання разом із індивідуальними зусиллями щодо пристосування до стресу та його подолання визначають вид та інтенсивність стресових реакцій. Намагання об’єднати когнітивні, емоційні та поведінкові стратегії, що використовуються для подолання стресу (технології копінгу), на жаль, не мають індивідуальних особливостей, зворотного зв'язку та цифрових трансформацій. Водночас стресовий процес значною мірою регулюється особистісними факторами, а також впливом соціуму під час дії стресора. Особистісні особливості разом з соціальними факторами можуть або сприяти стресовій реакції, або послаблювати іï, впливаючи на іï̈ тип, інтенсивність і тривалість. Тому слід підкреслити, що для ефективної адаптації до стресової ситуації необхідні знання ії об’єктивних і суб'єктивних параметрів: валентності, контрольованості, мінливості, невизначеності, повторюваності та поінформованості.

Відзначається, що третя фаза стресу — виснаження - за певних умов може супроводжуватися підвищеною тривожністю, а потім переходить в депресію, причому найчастіше це явище спостерігається у суб’ єктів, які і в нормальних умовах відрізнялися вираженим песимізмом. При цьому інтенсивність тривожності, що розвивається за адаптаційної реакції у людини, зазвичай, залежить не стільки від характеристик стресора, скільки від особистісної значимості чинного чинника $[11,19]$. 3 цього дуже важливого факту можна зробити два висновки: 1) один і той самий іспит може у різних студентів приводити до різноманітних психофізіологічних і соматичних проявів та 2) є вкрай важлива необхідність особистісного підходу до даної проблеми.
Дуже важливим фактом є також необхідність послідовних іспитів. Хоча після успішного складання першого іспиту емоційна напруга значно слабшає, вона, зазвичай, не опускається до фонових значень, бо лікар усвідомлює, що попереду його ще чекають інші випробування. Якщо ж лікар отримує оцінку нижче очікуваної, то тривожне очікування наступного іспиту може бути ще вищим [20, 23].

Для розуміння характеру взаємодії стресових подій розроблені різноманітні теоретичні моделі, що включають головні та буферні ефекти.

Стрес є складним психічним станом, що включає в себе декілька компонентів. Якщо розглядати стрес як загальний адаптаційний синдром за Г. Сельє [11], то це три різні стани організму: тривоги, опору та виснаження. Якщо розглядати стан стресу як вирішення організмом складних і важких завдань, що по силі й якісним особливостям залежать від стресора, як на це вказує М. Д. Лєвітов [6], то психічні стани за сильного страху та перевтоми різні, хоча в обох випадках наявний стрес.

Особливо важливим показником негативного стресу $є$ значне зниження стійкості психічних i психомоторних процесів, падіння працездатності. При діагностиці стресу спрощеним способом це є достатньо об’єктивним методом його виявлення [19, 21].

Вірогідність прогнозу в розвитку дистресу за непрямими ознаками може підтверджуватись вегетативними фізіологічними реакціями, наприклад помітним порушенням артеріального тиску за гіпертонічним або гіпотонічним типом, вегетативними порушеннями.

Розглянемо методики кількісної оцінки прогнозованого стресу: створення за допомогою різних пристроїв модельної стресової ситуації, яка за своїми параметрами була б досить близькою до ситуації реальної. Так, для оцінки поведінки тих, хто навчається, можливе проведення порівняння когнітивних чи психофізіологічних показників в декількох варіантах: при складанні тренувального іспиту, при виконанні інших тестів тощо. Зіставлення реакції лікарів на ситуацію іспиту з реакціями на цей тест показало, що подібні тестові завдання можуть бути своєрідними пробними моделями, вивчення яких дозволяє прогнозувати реакції того чи іншого випробуваного на реальну стресову ситуацію й оцінювання стресотолерантності $[12,14]$.

\section{Висновки.}

1. Екзаменаційна сесія - важка стресогенна ситуація, що вимагає від лікарів мобілізації 
внутрішніх і зовнішніх ресурсів як задля опанування самої ситуації, так і пристосування до зрушень в організмі та психіці, зумовлених екзаменаційним стресом. Відповідно, досягнення об'єктивних оцінок компетентності, знань та вмінь лікарів під час комп’ютерного тестування повністю залежить від забезпечення ефективної адаптації до зовнішніх і внутрішніх обставин іспиту.

2. Неодмінною складовою процесу комп’ютерного іспиту є організація процесу комплементарна до особистості, в результаті чого емоційне сприйняття процесу навчання буде позитивним, іспити формуватимуть позитивну самооцінку, процес засвоєння знань стане систематичним і цілісним.

3. Прогнозування стресових реакцій при комп’ютерному тестуванні лікарів має велике наукове та прикладне практичне значення, оскільки дозволяє заздалегідь виявляти осіб, у яких можливе порушення функціонального стану під час тестових іспитів, і проводити з ними відповідну роботу щодо психопрофілактики стресу.

\section{Література.}

1. Абабков В. А. Адаптация к стрессу. Основы теории, диагностики, терапии / В. А. Абабков, М. Перре. СПб. : Речь, 2004. - 166 с.

2. Бодров В. А. Информационный стресс : учебное пособие для вузов / В. А. Бодров. - М. : ПЕР СЭ, 2000. - 352 c.

3. Водопьянова Н. Е. Синдром выгорания: диагностика и профилактика / Н. Е. Водопьянова, Е. С. Старченкова. - СПб. : Питер, 2005. - 336 с.

4. Куликов Л. В. Стресс и стрессоустойчивость личности / Л. В. Куликов // Теоретические и прикладные вопросы психологи / Под ред. А. А. Крылова. Вып. 1.4.1. - СПб., 1995. - С. 123-132.

5. Лазарус Р. Теория стресса и психофизиологические исследования / Р. Лазарус // Эмоциональный стресс / Под ред. Л. Леви. — Л. : Медицина, 1970. — С. 178-207.

6. Левитов Н. Д. О психологических состояниях человека / Н. Д. Левитов. - М. : Просвещение, 1964. 344 c.

7. Марищук В. Л. Психологические основы формирования профессионально значимых качеств : автореф. дис. на соискание ученой степени д-ра психол. наук : спец. : 19.00.03 «Психология труда; инженерная психология» / В. Л. Марищук. — Л., 1982. — 42 с.

8. Марищук В. Л. Поведение и саморегуляция человека в условиях стресса / В. Л. Марищук, В. И. Евдокимов. - СПб. : ИД «Сентябрь», 2001. — 259 с.

9. Менегетти А. Психосоматика / А. Менегетти : пер. с итал. - М. : ННБФ «Онтопсихология», 2002. 328 c.
10. Парцерняк С. А. Стресс. Вегетозы. Психосоматика / С. А. Парцерняк. - СПб. : А. В. К., 2002. - 384 с.

11. Селье Г. Очерки об адаптационном синдроме / Г. Селье. — М. : Наука, 1979. - 126 с.

12. Судаков К. В. Психоэмоциональный стресс: профилактика и реабилитация / К. В. Судаков // Терапевтический архив. — 1997. — Т. 69, № 1. — С. 70-74.

13. Щербатых Ю. В. Психология стресса и методы коррекции / Ю. В. Щербатых. — СПб. : Питер, 2006. — 256 c.

14. Amutio A. Stress and irrational beliefs in college students / A. Amutio, J. C. Smith // Ansiedad y Estres. 2008. - Vol. 14, No.2-3. - P. 211-220.

15. Applied regression analysis and other multivariable methods / D. G. Kleinbaum, L. L. Kupper, K. E. Muller, A. Nizam. — Pacific Grove : Duxbury Press; 1998. 3rd ed. $-798 \mathrm{p}$.

16. Coping with examinations: exploring relationships between students' coping strategies, implicit theories of ability, and perceived control / J. Doron, Y. Stephan, J. Boiché, C. Le Scanff // Br. J. Educ. Psychol. 2009. - Vol. 79, Pt 3. - P. 515-528.

17. Davison C. B. A quantitative assessment of student performance and examination format / C. B. Davison, G. Dustova // Journal of Instructional Pedagogies. 2017. - Vol. 18. - P. 1-10.

18. Lemyre L. Mesure de stress psychologique (MSP): Se sentir stresse(e) / L. Lemyre, R. Tessier // Canadian Journal of Behavioural Science. - 1988. - Vol. 20, No. 3. - P. 302-321.

19. Myers, C. B. Assessing assessment: the effects of two exam formats on course achievement and evaluation / C. B. Myers, S. M. Myers // Innovative Higher Education. - 2006. - Vol. 31, No. 4. - P. 227-236.

20. O’Connor P. P. Practical reliability engineering / P. P. O’Connor, A. Kleyner. — Chichester : Wiley, 2012. — 5th ed. - $512 \mathrm{p}$.

21. Quantitative evaluation of the diagnostic thinking process in medical students / Y. Noguchi, K. Matsui, H. Imura [et al.] // J. Gen. Intern. Med. — 2002. Vol. 17, No. 11. - P. 848-853.

22. Shaunessy E. Strategies used by intellectually gifted students to cope with stress during their participation in a high school international baccalaureate program / E. Shaunessy, S. M. Suldo // Gifted Child Quarterly. 2010. — Vol. 54, No. 2. - P. 127-137.

23. Šimić N. Exam experience and some reactions to exam stress / N. Šimić, I. Manenica // Fiziol. Cheloveka. 2012. — Vol. 38, No. 1. - P. 82-87.

24. Students' emotions, physiological reactions, and coping in academic exams / G. Spangler, R. Pekrun, K. Kramer, H. Hofmann // Anxiety, Stress \& Coping. — 2002. Vol. 15, No. 4. - P. 413-432. 


\section{References.}

1. Ababkov, V. A., \& Perre, M. (2004). Adaptatsiya k stressu. Osnovy teorii, diagnostiki, terapii [Adaptation to stress. Fundamentals of theory, diagnosis, therapy]. St. Petersburg: Rech (Language).

2. Bodrov, V.A. (2000). Informatsionnyi stress [Information stress]: textbook. Moscow: PER SE.

3. Vodop’yanova, N. E., \& Starchenkova, E. S. (2005). Sindrom vygoraniya: diagnostika I profilaktika [Burnout syndrome: diagnosis and prevention]. St. Petersburg: Piter.

4. Kulikov, L. V. (1995). Stress i stressoustoichivost' lichnosti [Stress and personality stress-resistance]. In A. A. Kryilova (ed.). Teoreticheskie I prikladnye voprosy psikhologii (Theoretical and applied questions of psychology) Iss. 1.4.1 (pp. 123-132).

5. Lazarus, R.(1970). Teoriya stressaipsikhofiziologicheskie issledovaniya [Theory of stress and psychophysiological studies]. In L. Levi (ed.). Emotsional'nyi stress (Emotional stress) (178-207). Leningrad: Medicine.

6. Levitov, N. D. (1964). O psikhologicheskikh sostoyaniyakh cheloveka [On the psychological conditions of man]. Moscow: Prosveshchenie (Education).

7. Marishchuk, V. L. (1982). Psikhologicheskie osnovy formirovaniya professional'no znachimykh kachestv. (Doctoral dissertation). Available from disserCat dissertations electronic library.

8. Marishchuk, V. L., \& Evdokimov, V. I. (2001). Povedenie i samoregulyatsiya cheloveka v usloviyakh stressa [Behavior and self-regulation of a person under stress]. St. Petersburg: Publishing house «September».

9. Menegetti, A. (2002). Psikhosomatika [Psychosomatics]. Moscow: NNBF «Ontopsychology».

10. Partsernyak, S. A. (2002). Stress. Vegetozy. Psikhosomatika [Stress. Vegetosis. Psychosomatics]. St. Petersburg: A. V. K.

11. Selye, H. (1979). Ocherki ob adaptatsionnom sindrome [Essays on the adaptation syndrome]. Moscow: Nauka (Science).

12. Sudakov, K. V. (1997). Psikhoemotsional'nyi stress: profilaktika i reabilitatsiya [Psychoemotional stress: prevention and rehabilitation]. Terapevticheskii arkhiv (Therapeutic archive), 69(1), 70-74.

13. Shcherbatykh, Yu. V. (2006). Psikhologiya stressa i metody korrektsii [Psychology of stress and correction methods]. St. Petersburg: Piter.

14. Amutio, A., \& Smith, J. C. (2008). Stress and irrational beliefs in college students. Ansiedad y Estres, 14(2-3), 211-220.

15. Kleinbaum, D. G., Kupper, L. L., Muller, K. E., \& Nizam, A. (1998). Applied regression analysis and other multivariable methods. 3rd ed. Pacific Grove: Duxbury Press.

16. Doron, J, Stephan, Y, Boiché, J \& Le Scanff, C. (2009). Coping with examinations: exploring relationships between students' coping strategies, implicit theories of ability, and perceived control. Br. J. Educ. Psychol., 79, 515-528.

17. Davison, C. B., \& Dustova, G. (2017). A quantitative assessment of student performance and examination format. Journal of Instructional Pedagogies, 18, 1-10.

18. Lemyre, L., \& Tessier, R. (1988). Mesure de stress psychologique (MSP): Se sentir stresse(e). Canadian Journal of Behavioural Science, 20(3), 302-321.

19. Myers, C. B. \& Myers, S. M. (2006). Assessing assessment: the effects of two exam formats on course achievement and evaluation. Innovative Higher Education, 31(4), 227-236.

20. O’Connor, P. P., Kleyner, A. (2012). Practical reliability engineering. 5th ed. Chichester: Wiley.

21. Noguchi, Y., Matsui, K., Imura, H., Kiyota, M., \& Fukui, T. (2002). Quantitative evaluation of the diagnostic thinking process in medical students. J. Gen. Intern. Med., 17(11), 848-853.

22. Shaunessy, E., \& Suldo, S. M. (2010), Strategies used by intellectually gifted students to cope with stress during their participation in a high school international baccalaureate program. Gifted Child Quarterly, 54(2), 127-137.

23. Šimić, N., Manenica, I. (2012). Exam experience and some reactions to exam stress. Fiziol. Cheloveka, 38(1), 67-72.

24. Spangler, G., Pekrun, R., Kramer, K. \& Hofmann, H. (2002), Students' emotions, physiological reactions, and coping in academic exams. Anxiety, Stress \& Coping, 15(4), 413-432. 